Vol 12, Issue 4, 2019

\title{
BLOOD PRESSURE LOWERING EFFECT OF POLYHERBAL PREPARATION CONTAINING ALLIUM SATIVUM, BELERICAE FRUCTUS, CURCUMA AERUGINOSA, AND AMOMI FRUCTUS ON RAT MODEL OF HYPERTENSION
}

\section{DWI ARIS AGUNG NUGRAHANINGSIH*, SHOLIKHAH EN, MUSTOFA M, YULIANI FS, PURWONO S, NGATIDJAN N}

Department of Pharmacology and Therapy, Faculty of Medicine, Universitas Gadjah Mada, Yogyakarta, Indonesia. Email: dwi.aris.a@ugm.ac.id

Received: 29 December 2018, Revised and Accepted: 20 March 2019

\section{ABSTRACT}

Objective: The study aimed to investigate the blood pressure lowering effect of the polyherbal preparation contains Allium sativum, Belericae fructus, Curcuma aeruginosa, and Amomi fructus in the animal model of hypertension.

Methods: Deoxycorticosterone acetate uninephrectomy salt rat model was used to develop hypertension model. Hypertensive rats were divided into five groups that were no treatment (negative control group [NEG]), hydrochlorothiazide treatment, polyherbal preparation $63 \mathrm{mg} / \mathrm{kg}$ treatment (DOSE 1), polyherbal preparation $126 \mathrm{mg} / \mathrm{kg}$ treatment (DOSE 2), and polyherbal preparation $252 \mathrm{mg} / \mathrm{kg}$ treatment (DOSE 3). The treatment was started after hypertension developed and given for 3 weeks.

Results: The result showed that the mean of systolic blood pressure in DOSE 2 group was significantly lower compared with those on NEG group (145.86 mmHg vs. $174.71 \mathrm{mmHg}, \mathrm{p}<0.05)$.

Conclusion: Our study provides evidence to support the use of the polyherbal preparation containing A. sativum, B. fructus, C. aeruginosa, and A. fructus for lowering blood pressure.

Keywords: Polyherbal preparation, Allium sativum, Belericae fructus, Curcuma aeruginosa, Amomi fructus, Hypertension.

(C) 2019 The Authors. Published by Innovare Academic Sciences Pvt Ltd. This is an open access article under the CC BY license (http://creativecommons. org/licenses/by/4. 0/) DOI: http://dx.doi.org/10.22159/ajpcr.2019.v12i4.31750

\section{INTRODUCTION}

Many traditional medications from herbal preparations are used in the mixture formulation. When it is in single herbal preparation, it often loses its expected pharmacological effect. Therefore, instead of investigating every single compound of the traditional herbal preparation pharmacological effect, using the original formula of herbal preparation which already proven its effectiveness for many decades will be far more promising.

Allium sativum, Belericae fructus, Curcuma aeruginosa, and Amomi fructus are kind of spice which often use for cooking whether alone or as a mixture with other spices. The mixture of A. sativum, B. fructus, $C$. aeruginosa, and $A$. fructus is preparation which has been used for hypertension treatment for years in Indonesia.

A. sativum or garlic bulb, B. fructus or jelawe, C. aeruginosa or temu ireng rhizome, and $A$. fructus or kapulaga have been widely used by people in Indonesia. Garlic bulb (A. sativum) is an herb that has been used to treat cardiovascular problems. Results of a meta-analysis study showed that the A. sativum lower blood pressure in hypertensive patients but not in people with normal blood pressure [1]. The clinical study also indicates that $A$. sativum can lower blood pressure when compared with placebo [2]. Meanwhile, $B$. fructus or Terminalia bellerica or known as jelawe in Indonesia is also proved to have antioxidant and antihypertensive effects $[3,4]$. C. aeruginosa rhizome or locally known as temu ireng has demonstrated activity as an antioxidant [5,6]. The other ingredient, A. fructus, also has many therapeutic effects such as anti-inflammatory, analgesics, and gastrointestinal protections [7]. Despite the long history of the polyherbal preparation as blood pressure lowering medicine, its activity toward blood pressure has not been proven scientifically. As a single preparation, A. sativum has been found to be effective to reduce blood pressure in hypertension patient [1]. However, combination of $A$. sativum with other herbals which also known to have either antihypertension or antioxidant activity such the polyherbal that had long been used in Indonesia is not yet known. Therefore, our study aims to investigate polyherbal preparation containing A. sativum, B. fructus, C. aeruginosa, and A. fructus blood pressure lowering effects on a hypertensive rat model.

\section{MATERIALS AND METHODS}

The protocol of this study has been reviewed and approved by Faculty of Medicine Universitas Gadjah Mada Ethical Committee with approval number KE/FK/58/EC/2016.

\section{Polyherbal preparation}

The polyherbal preparation was prepared by PT Marguna Tarulata APK Farma, Tegal, Indonesia. The polyherbal contains powder of A. sativum bulbus $180 \mathrm{mg}$, B. fructus $60 \mathrm{mg}$, C. aeruginosa rhizome $60 \mathrm{mg}$, and $A$. fructus $35 \mathrm{mg}$.

\section{Animal experiment}

The experiment was conducted using 12-16-week-old Wistar rat. The rats were kept in an individual cage and housed under maintained temperature and humidity house with 12:12-h light-dark cycle and free access to food and drink. The increase of the blood pressure is induced by unilateral nephrectomy followed by deoxycorticosterone acetate (DOCA)-salt administration. The left unilateral nephrectomy was done to all rats. 1 week after the unilateral nephrectomy surgery, DOCA was given twice a week at $25 \mathrm{mg} / \mathrm{kg}$ BW and the drink was changed into $\mathrm{NaCl} 0.9 \%$ and $\mathrm{KCl} 0.2 \%$. Observation of the condition was performed every day during the study. At week 6 of DOCA administration, the rats were divided into five groups which are negative control group (NEG) that received aquadest $4 \mathrm{~mL} / \mathrm{kg} \mathrm{BW}$, 
positive control group (hydrochlorothiazide treatment [HCT]) that received hydrochlorothiazide $3 \mathrm{mg} / \mathrm{kg} \mathrm{BW}$, polyherbal extract $63 \mathrm{mg} / \mathrm{kg}$ BW group (DOSE 1), polyherbal extract $126 \mathrm{mg} / \mathrm{kg}$ BW group (DOSE 2), and polyherbal extract $252 \mathrm{mg} / \mathrm{kg}$ BW group (DOSE 3). The dose used is chosen based on the dose conversion from the human recommended dose of the polyherbal preparation. The treatment was given orally every day for 3 weeks. The blood pressure was measured weekly using CODA tail cuff blood pressure machine.

\section{Data analysis}

The data are presented as mean \pm standard error of mean. The analysis was performed by one-way ANOVA followed by post hoc analysis using GraphPad Prism software. $\mathrm{p}<0.05$ was considered as statistically significant.

\section{RESULTS AND DISCUSSION}

Results

The treatment given for 3 weeks did not change the body weight of the rats. The body weight measurement result at 3 weeks after treatment is showed in Fig. 1.

The heart rate and blood pressure measurement were measured by indirect methods using tail cuff blood pressure measurement machine. The heart rate measurement is showed in Fig. 2. The heart rate was the same among all groups of treatment.

The systolic blood pressure measured after 3 weeks of treatment is shown in Fig. 3. The mean of systolic blood pressure on the HCT group and DOSE 2 group was lower compared with those on the NEG group. Interestingly, the difference in systolic blood pressure between DOSE 3 group and NEG group was not statistically significant $(n=5)$.

We also calculate the systolic blood pressure change by subtracting the systolic blood pressure after treatment (week 8) with the systolic blood pressure before treatment (week 6). Systolic blood pressure change is showed in Fig. 4.

The result shows that the systolic blood pressure change was positive in the HCT group, DOSE 1 group, and DOSE 2 group. Meanwhile, NEG group and DOSE 3 group show negative systolic blood pressure change. Positive blood pressure change indicates that the blood pressure after treatment is lower compared to those before treatment. Meanwhile, negative systolic blood pressure change shows that the blood pressure before treatment is higher compared to those before treatment. The systolic blood pressure change is significantly higher in HCT group and DOSE 2 group. Meanwhile, the systolic blood pressure change is not different between DOSE 1 group, DOSE 3 group, and NEG group.

\section{Discussion}

The administration of DOCA, a synthetic mineralocorticoid, with $\mathrm{NaCl}$ $0.9 \%$ and $\mathrm{KCl} 0.2 \%$ to uninephrectomized Wistar rat is one of the animal models for hypertension. The blood pressure increased in this model is suggested to be the result of excess body fluid volume [8]

After 3 weeks of therapy, it appears that systolic blood pressure in the HCT group was the lowest compared to those on the other groups. We suggest that it caused by the diuretic effect of hydrochlorothiazide. Hydrochlorothiazide is known as one of the first-line drugs for uncomplicated hypertension [9]. The mechanism of the action of hydrochlorothiazide in lowering blood pressure is not known clearly. The blood pressure lowering effect of hydrochlorothiazide is known to be the result of two mechanisms which are direct action on the endothelial and smooth muscle of blood vessels causing vasodilatation and indirect effects by decreasing cardiac output which occurs due to the mechanism of the action of hydrochlorothiazide in $\mathrm{Na}+\mathrm{Cl}$ cotransporter in distal convoluted tubule that regulates $\mathrm{Na}$ absorption which causes diuresis [10].

The systolic blood pressure in the polyherbal preparation group was lower compared with those on the NEG group. However, only systolic

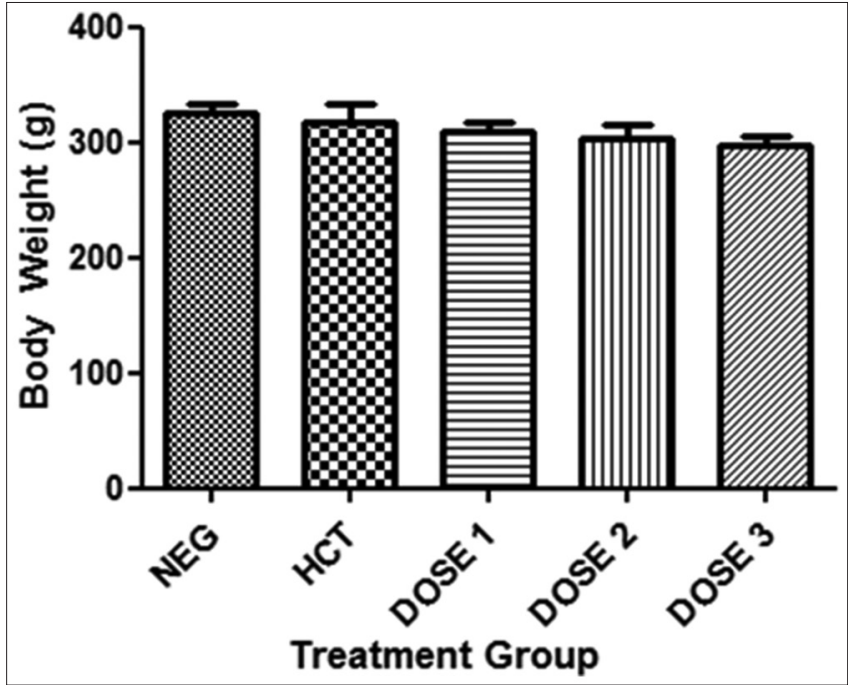

Fig. 1: The mean body weight of the rats after 3 weeks of treatment in all groups (g) (mean \pm standard error of mean). Negative control group received aquadest $4 \mathrm{~mL} / \mathrm{kg} \mathrm{BW}$, positive control group (hydrochlorothiazide treatment) received hydrochlorothiazide $3 \mathrm{mg} / \mathrm{kg} \mathrm{BW}$, polyherbal extract $63 \mathrm{mg} / \mathrm{kg}$ BW group (DOSE 1), polyherbal extract $126 \mathrm{mg} / \mathrm{kg}$ BW group (DOSE 2), and polyherbal extract $252 \mathrm{mg} / \mathrm{kg}$ BW group (DOSE 3). No significant differences in body weight at 3 weeks after treatment among groups $(n=5)$

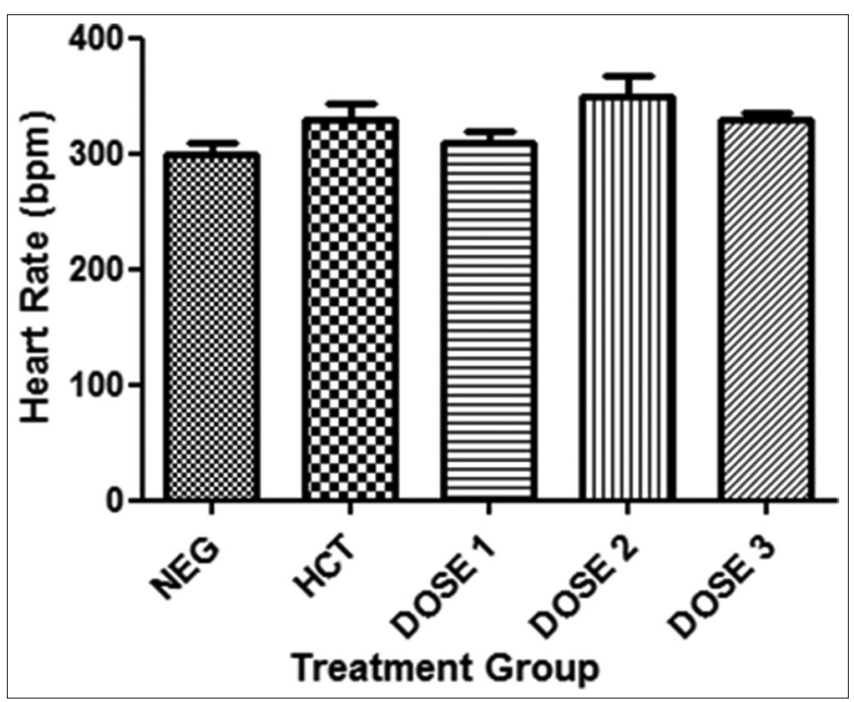

Fig. 2: The mean heart rate of the rats after 3 weeks of treatment in all groups (beat per minute/bpm) (mean \pm standard error of mean). Negative control group received aquadest $4 \mathrm{~mL} / \mathrm{kg} \mathrm{BW}$, positive control group (hydrochlorothiazide treatment) received hydrochlorothiazide $3 \mathrm{mg} / \mathrm{kg} B W$, polyherbal extract $63 \mathrm{mg} / \mathrm{kg}$ BW group (DOSE 1), polyherbal extract $126 \mathrm{mg} / \mathrm{kg}$ BW group (DOSE 2), and polyherbal extract $252 \mathrm{mg} / \mathrm{kg}$ BW group (DOSE 3). No significant differences in heart rate at 3 weeks after treatment among groups $(n=5)$

blood pressure in DOSE 2 group was lower statistically compare to those on the NEG group. This is probably due to the difference in the mechanism of the action of polyherbal preparation with hydrochlorothiazide.

Polyherbal preparation tablets contain garlic bulbs (A. sativum), jelawe ( $T$. bellerica), temu ireng rhizome (C. aeruginosa), and cardamom (A. fructus). Garlic bulb (A. sativum) is an herb that has been widely used empirically to treat hypertension. A clinical study showed that $A$. sativum 


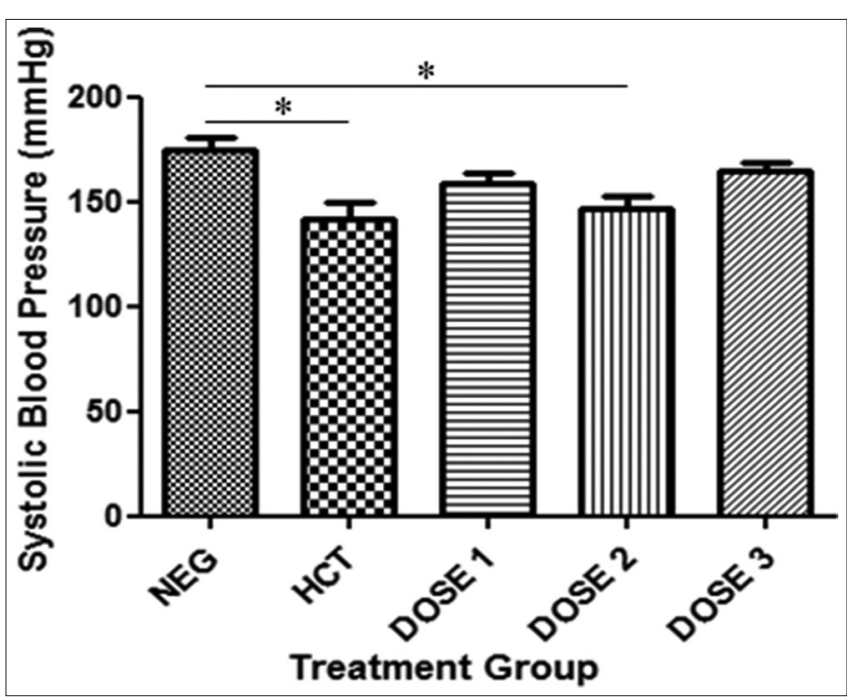

Fig. 3: The mean of systolic blood pressure of the rats after 3 weeks of treatment ( $\mathrm{mmHg}$ ) (mean \pm standard error of mean). Negative control group received aquadest $4 \mathrm{~mL} / \mathrm{kg} \mathrm{BW}$, positive control group (hydrochlorothiazide treatment) received hydrochlorothiazide $3 \mathrm{mg} / \mathrm{kg} \mathrm{BW}$, polyherbal extract $63 \mathrm{mg} / \mathrm{kg}$ BW group (DOSE 1), polyherbal extract $126 \mathrm{mg} / \mathrm{kg}$ BW group (DOSE 2), and polyherbal extract $252 \mathrm{mg} / \mathrm{kg}$ BW group (DOSE 3). $*(p<0.05)(n=5)$

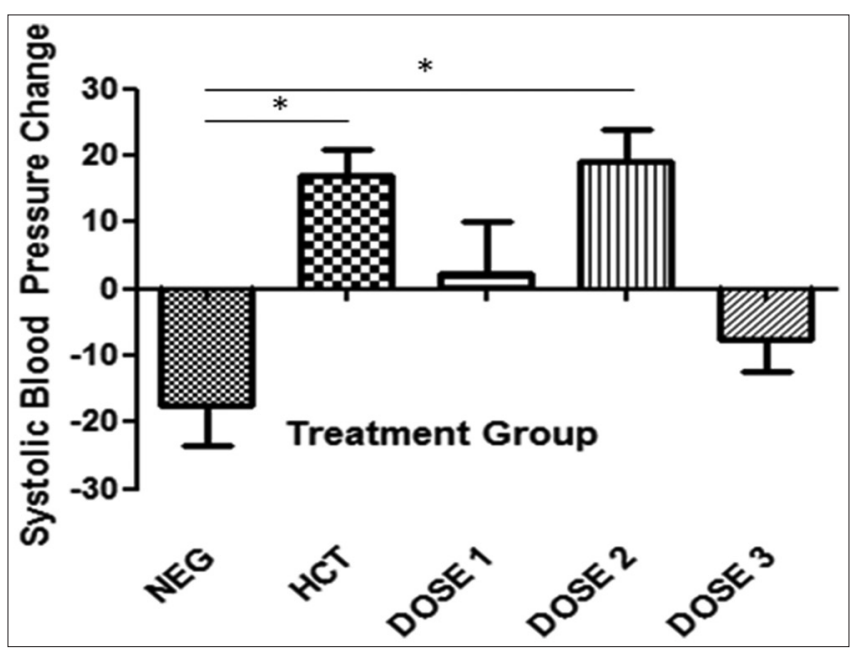

Fig. 4: The mean of systolic blood pressure change after 3 weeks of treatment (mean \pm standard error of mean). Negative control group received aquadest $4 \mathrm{~mL} / \mathrm{kg} \mathrm{BW}$, positive control group (hydrochlorothiazide treatment) received hydrochlorothiazide $3 \mathrm{mg} / \mathrm{kg} \mathrm{BW}$, polyherbal extract $63 \mathrm{mg} / \mathrm{kg}$ BW group (DOSE 1), polyherbal extract $126 \mathrm{mg} / \mathrm{kg}$ BW group (DOSE 2), and polyherbal extract $252 \mathrm{mg} / \mathrm{kg}$ BW group (DOSE 3$).{ }^{*}(\mathrm{p}<0.05)(\mathrm{n}=5)$

not only has an effect on blood pressure but also has antioxidant effects and immune-modulatory effect $[11,12]$. The study on the active compound of A. sativum showed that garlic contains various functional compounds, i.e., hydroxyl, carbonyl, carboxylic, organosulfur, and aromatic compounds which might be responsible for its pharmaceutical activity [13]. The study of $A$. sativum on rat with two kidneys, one clip model of hypertension, showed that garlic blood pressure lowering activity is mediated by its activity on modulating nitric oxide which then causes vasodilatation [14]. Research on jelawe (B. fructus) showed that jelawe has antihypertensive and antioxidant effects $[3,4]$. B. fructus showed its antihypertensive effect by antagonizing the calcium (Ca) channel which was examined using rabbit thoracic aorta in vitro [4]. Meanwhile, temu ireng rhizome ( $C$. aeruginosa) also has antioxidant activity $[5,6]$. Based on those studies, we suggest that the mechanism of the action of polyherbal preparation on blood pressure could be through the antioxidant effect of the polyherbal compound.

The buildup of reactive oxygen species (ROS) is one of the mechanisms that play a role in the rise in blood pressure [15]. Some sources of oxidant are known to be present in hypertension such as NADPH oxidase, mitochondria, xanthine oxidase, endothelium nitric oxide synthase, cyclooxygenase, and cytochrome P450 epoxygenase [16]. The previous research has shown that administration of antioxidants rich diets has been shown to lower blood pressure in both animal and human models [16-18]. Antioxidant not only can improve blood pressure control but also can prevent the development of endothelial dysfunction and improve cardiovascular risk in the hypertensive patient. Ramipril, an angiotensin-converting enzymes inhibitor, shows its antioxidant effect on the patient with hypertension $[16,19]$.

Antioxidants are needed to counteract oxidative stress in the body. However, high dose antioxidants can cause body function disorders because they provide pro-oxidant effects and disturb the balance of ROS in the body that actually is still needed to maintain the balance of body function [20]. The previous studies have shown that administration of antioxidants in high doses actually has a pro-oxidant effect [21]. Some antioxidant agent also has potential as pro-oxidant [16]. Those may be the reasons why in the highest dose of polyherbal preparation, the blood pressure did not decrease the blood pressure.

\section{CONCLUSION}

Polyherbal preparation contains garlic bulbs (A. sativum), jelawe ( $T$. bellerica), temu ireng rhizome ( $C$. aeruginosa), and cardamom (A. fructus) and shows the potential to be developed as a blood pressure lowering agent.

\section{ACKNOWLEDGMENT}

The author would like to thank Mosa Rini Nurhidayati, Nurhadi, and Suroso for the technical support. This study was supported by the Ministry of Higher Education and Technology Republic of Indonesia by Penelitian Unggulan Perguruan Tinggi Grant 2016-2018.

\section{AUTHORS' CONTRIBUTIONS}

Fara Silvia Yuliani and Setyo Purwono were supporting the design of the study and conducting the study along with Dwi Aris Agung Nugrahaningsih. Eti Nurwening Sholikhah, Mustofa, and Ngatidjan have proofread the manuscript and recommend the critical revision to the manuscript drafted by Dwi Aris Agung Nugrahaningsih.

\section{CONFLICTS OF INTEREST}

There are no conflicts of interest regarding the publication of the manuscript.

\section{REFERENCES}

1. Reinhart KM, Coleman CI, Teevan C, Vachhani P, White CM. Effects of garlic on blood pressure in patients with and without systolic hypertension: A meta-analysis. Ann Pharmacother 2008;42:1766-71

2. Ried K, Frank OR, Stocks NP, Fakler P, Sullivan T. Effect of garlic on blood pressure: A systematic review and meta-analysis. BMC Cardiovasc Disord 2008;8:13.

3. Saraswathi NM, Karthikeyan M, Kannan M, Rajasekar S. Terminalia bellerica roxb. A phytopharmacological review. Int J Res Pharm Biomed Sci 2012;3:96-9.

4. Khan AU, Gilani AH. Pharmacodynamic evaluation of Terminalia belerica for its antihypertensive effect. J Food Drug Anal 2008;16:6-14.

5. Choudhury D, Ghosal M, Das AP, Mandal P. Development of single node cutting propagation techniques and evaluation of antioxidant activity of $C$. aeruginosa, Roxburg hrizhome. Int J Pharm Pharm Sci 2013;5:227-34.

6. Nurcholis W, Priosoeryanto BP, Purwakusumah ED, Katayama T, Suzuki T. Antioxidant, cytotoxic activities and total phenolic content of 
four Indonesian medicinal plants. Valensia 2012;2:501-10.

7. Suo S, Lai Y, Li M, Song Q, Cai J, Zhao J, et al. Phytochemicals, pharmacology, clinical application, patents, and products of Amomi fructus. Food Chem Toxicol 2018;119:31-6.

8. Pinto YM, Paul M, Ganten D. Lessons from rat models of hypertension: From goldblatt to genetic engineering. Cardiovasc Res 1998;39:77-88

9. James PA, Oparil S, Carter BL, Cushman WC, Dennison-Himmelfarb C, Handler J, et al. 2014 evidence-based guideline for the management of high blood pressure in adults: Report from the panel members appointed to the eighth joint national committee (JNC 8). JAMA 2014;311:507-20.

10. Duarte JD, Cooper-DeHoff RM. Mechanisms for blood pressure lowering and metabolic effects of thiazide and thiazide-like diuretics. Expert Rev Cardiovasc Ther 2010;8:793-802.

11. Dhawan V, Jain S. Effect of garlic supplementation on oxidized low density lipoproteins and lipid peroxidation in patients of essential hypertension. Mol Cell Biochem 2004;266:109-15.

12. Pramod SN, Vellingiri V, Venkatesh YP. Immunomodulatory effects of hemagglutinating lectins from potato (Solanum tuberosum) and garlic (Allium sativum) on human and murine lymphocytes. Int J Pharm Pharm Sci 2015;7 Supp 1:147-53.

13. Divya BJ, Suman B, Venkataswamy M, Thyagaraju K. A study on phytochemical, functional groups and mineral composition of Allium sativum (garlic) cloves. Int J Curr Pharm Res 2016;9:42-5.

14. Al-Qattan KK, Thomson M, Al-Mutawa'a S, Al-Hajeri D, Drobiova H, Ali M. Nitric oxide mediates the blood-pressure lowering effect of garlic in the rat two-kidney, one-clip model of hypertension. J Nutr 2006; $136: 774$ S-6S.

15. Sinha N, Dabla PK. Oxidative stress and antioxidants in hypertension-a current review. Curr Hypertens Rev 2015;11:132-42.

16. Kizhakekuttu TJ, Widlansky ME. Natural antioxidants and hypertension: Promise and challenges. Cardiovasc Ther 2010;28:e20-32.

17. Safaeian L, Ghannadi A, Javanmard SH, Vahidian MH. The effect of hydroalcoholic extract of Ferula foetida stems on blood pressure and oxidative stress in dexamethasone-induced hypertensive rats. Res Pharm Sci 2015;10:326-34

18. Kardum N, Milovanović B, Šavikin K, Zdunić G, Mutavdžin S, Gligorijević $\mathrm{T}$, et al. Beneficial effects of polyphenol-rich chokeberry juice consumption on blood pressure level and lipid status in hypertensive subjects. J Med Food 2015;18:1231-8

19. Tamuli S, Kakati S, Das S, Singh KD, Ghosh SK. Comparative studies of efficacy and effect of oxidative stress of amlodipine and ramipril in the hypertensive patients of North East India. Int J Pharm Pharm Sci 2015;7:118-21.

20. Bouayed J, Bohn T. Exogenous antioxidants - double-edged swords in cellular redox state: Health beneficial effects at physiologic doses versus deleterious effects at high doses. Oxid Med Cell Longev 2010;3:228-37.

21. Weinberg RB, VanderWerken BS, Anderson RA, Stegner JE, Thomas MJ. Pro-oxidant effect of Vitamin E in cigarette smokers consuming a high polyunsaturated fat diet. Arterioscler Thromb Vasc Biol 2001;21:1029-33. 